\title{
Iron associated with asbestos bodies is responsible for the formation of single strand breaks in $\varphi$ X174 RFI DNA
}

\author{
L G Lund, M G Williams, R F Dodson, A E Aust
}

\begin{abstract}
The ability of amosite cored asbestos bodies isolated from human lungs to catalyse damage to $\varphi \times 174$ RFI DNA in vitro was measured and compared with that of uncoated amosite fibres with a similar distribution of length. Asbestos bodies ( 5000 bodies) suspended for 30 minutes in $50 \mathrm{mM} \mathrm{NaCl}$ containing 0.5 $\mu \mathrm{g} \varphi \mathrm{X174}$ RFI DNA, pH 7·5, did not catalyse detectable amounts of DNA single strand breaks. Addition of the reducing agent ascorbate $(1 \mathrm{mM})$, however, resulted in single strand breaks in $10 \%$ of the DNA. Asbestos bodies in the presence of a low molecular weight chelator ( $1 \mathrm{mM}$ ) and ascorbate catalysed the formation of single strand breaks in $21 \%$ of the DNA with citrate or $77 \%$ with ethylenediamine tetra-acetic acid (EDTA), suggesting that mobilisation of iron may increase damage to DNA. Preincubation for 24 hours with desferrioxamine $B$, which binds iron (Fe (III)) and renders it redox inactive, completely inhibited the reactivity of asbestos bodies with DNA, strongly suggesting that iron was responsible. Amosite fibres (5000 fibres/reaction), with a similar length distribution to that of the asbestos bodies, did not catalyse detectable amounts of single strand breaks in DNA under identical reaction conditions. The results of the present study strongly suggest that iron deposits on the amosite core asbestos bodies were responsible for the formation of DNA single strand breaks in vitro. Mobilisation of iron by chelators seemed to enhance the reactivity of asbestos bodies with DNA. It has been postulated that the in vivo deposition of the coat material on to fibres may be an attempt by the lung defences to isolate the fibre from the lung surface and thus offer a protective mechanism from physical irritation. These results suggest, however, that the iron that is deposited on asbestos fibres in vivo may be reactive, potentially increasing the damage to biomolecules, such as DNA, above that of the uncoated fibres.
\end{abstract}

(Occup Environ Med 1994;51:200-204)

Inhalation of asbestos fibres is known to increase the risk of lung carcinoma and pleural mesothelioma. ${ }^{1}$ Asbestos bodies are fibres of asbestos coated with mucopolysac- charides, protein, and iron (hence the term ferruginous). ${ }^{2-6}$ The presence of these bodies in the lungs of subjects has been used as an indication of previous exposure to asbestos. ${ }^{5}$ In animal studies, Gross et al described the formation of a ferruginous coating on both fibrous and non-fibrous particulates. ${ }^{78}$ Whereas those formed on non-asbestos fibres were reported by light microscopy to be similar to asbestos bodies, present guidelines recommend that such structures from human samples be considered asbestos bodies only if the core is colourless and transparent. ${ }^{9}$ The only technique for true identification of the core material is analytical electron microscopy. ${ }^{210}$ Whereas amphiboles are often seen in the core of asbestos bodies, longer chrysotile fibres can also serve as suitable core material when an appropriate quantity of fibres are inhaled. ${ }^{11}$

The number of inhaled fibres that become coated to form asbestos bodies in the lung is highly variable. In fact, some humans (and certain animal species) are very inefficient at coating asbestos fibres. ${ }^{12}$ The most generally accepted theory is that most humans coat a population of the longer fibres and that the process of coating affords protection to the tissue from the physical threat of the needlelike fibres. ${ }^{34}$ There seem to be several variables that contribute to the coating efficiency. Factors that seem to be important in the fibres are length, physical characteristics, ${ }^{13} 14$ and number of fibres inhaled. ${ }^{215}$ The factor that seems to be most important is the coating ability of the macrophages. ${ }^{12} 16$ Although the mechanism of formation of these bodies is not completely understood, it is thought that a mucopolysaccharide matrix is deposited on the fibre, then iron is deposited by macrophages. ${ }^{41718}$ Electron microscopy has been used to show that the coat material consists of dense granules about $6 \mathrm{~nm}$ in diameter. These granules are thought to represent either ferritin, ${ }^{19}$ an iron storage protein, or haemosiderin, ${ }^{36}$ a presumed breakdown product of ferritin.

There is accumulating published evidence showing that iron on or from asbestos fibres is responsible for the biochemical reactions attributed to asbestos in vitro. ${ }^{20}$ Iron has been shown to be responsible for asbestos dependent oxygen consumption, ${ }^{21}{ }^{22}$ hydroxyl radical formation, ${ }^{22-24}$ lipid peroxidation in vitro ${ }^{25}$ and in cultured cells, ${ }^{26-28}$ and damage to DNA. ${ }^{27} 2930$ The ability of iron deposited in the ferruginous coat of asbestos bodies to undergo redox reactions with oxygen

Requests for reprints to: Accepted 7 June 1993 
(Haber-Weiss reaction) to catalyse damage to biomolecules, such as DNA, has never been investigated.

The purpose of the experiments presented here was to compare the ability of iron associated with the coat of amosite cored asbestos bodies with the ability of uncoated amosite fibres to catalyse the formation of DNA single strand breaks in vitro. The addition of a chelator-for example, ethylenediamine tetra-acetic acid (EDTA) or citrate-and a reducing agent, ascorbate, enabled better comparisons of reactions with the coated $v$ uncoated fibres. The asbestos bodies obtained for this study were from a patient with a documented occupational exposure to only the amosite form of asbestos. Examination of the core composition by electron microscopy confirmed the homogeneity of the uncoated fibres and asbestos body cores and confirmed their elemental composition as ferromagnesium silicates.

\section{Materials and methods}

ASBESTOS BODIES, ASBESTOS, AND REAGENTS Amosite asbestos bodies were obtained from the lung tissue of a dead 68 year old insulator who had adenocarcinoma. The tissue, fixed in $10 \%$ formalin, was rinsed in deionised water, dehydrated overnight in $95 \%$ ethanol, rinsed a second time in water, and digested in 9.2\% sodium hypochlorite (Wright Bleach, Wright Inc, Ft Worth, TX, USA). The asbestos bodies in the digest were isolated from the uncoated asbestos fibres by sedimentation and multiple water rinses. All reagents were prefiltered through $0.2 \mu \mathrm{m}$ nucleopore polycarbonate filters before use. Some of the isolated amosite asbestos bodies and a portion of the fixed lung tissue were embedded in Spur's plastic ${ }^{31}$ and sectioned for transmission electron microscopy.

Sized amosite asbestos fibres were isolated from a sample provided by the National Institute of Environmental Health Sciences. Initially, unground amosite asbestos fibres were suspended in deionised water and the large and small fibre fractions were removed by sedimentation and multiple rinses, until a fraction with lengths similar to those of the asbestos bodies was obtained. These fibres were readily visible by phase contrast microscopy because their diameters greatly exceeded the resolution of the microscope. Therefore, lengths of the asbestos bodies and asbestos fibres were measured by light microscopy. The distributions were obtained by randomly measuring 100 asbestos bodies or fibres with a Walton-Beckett graticule at $400 \times$ magnification.

The identities of the asbestos body cores and fibres were confirmed by energy dispersive $x$ ray analysis and electron diffraction in a JEOL 100CX analytical electron microscope equipped with a TN $2000 x$ ray analyser.

Fibre and asbestos body concentrations were determined by filtering aliquots of the solutions through $0.45 \mu \mathrm{m}$ mixed cellulose ester filters (Millipore) that were then dried and subsequently cleared with acetone vapour. The fibres and asbestos bodies were counted by NIOSH 7400 rules at a magnification of $400 \times$ magnification with a Walton-Beckett graticule.

Closed circular superhelical $\varphi$ X174 RFI DNA was obtained from New England Biolabs (Beverly, MA, USA). DNA was removed from the shipping buffer by ethanol precipitation, as described by Maniatis et al ${ }^{32}$ and redissolved in $50 \mathrm{mM} \mathrm{NaCl}, \mathrm{pH} \mathrm{7.5}$. The sodium salt of L-ascorbic acid was obtained from Sigma Chemical Co (St Louis, MO, USA); sodium citrate and the disodium salt of EDTA from Mallinckrodt, Inc (Paris, KY, USA); Deferoxamine mesylate USP (desferrioxamine B) from CIBA (Summit, NJ, USA); and Chelex 100 from Bio-Rad Laboratories (Richmond, CA, USA). Contaminating metals were removed from 50 $\mathrm{mM} \mathrm{NaCl}$ by chromatography with Chelex 100. The remaining solutions were then prepared with chelex treated $\mathrm{NaCl}$. Stock solutions of ascorbate were prepared immediately before use. All solutions were prepared under incandescent yellow lights and stored in the dark.

INDUCTION OF SINGLE STRAND BREAKS IN DNA BY ASBESTOS BODIES OR SIZED AMOSITE FIBRES Induction of single strand breaks in DNA was measured as described previously. ${ }^{29}$ Briefly, asbestos bodies or similarly sized amosite fibres (5000 bodies or fibres/reaction) were incubated with $\varphi$ X174 RFI DNA $(0.5 \mu \mathrm{g})$, $1 \mathrm{mM}$ chelator (citrate, EDTA), or $1 \mathrm{mM}$ ascorbate or both for 30 minutes in $50 \mathrm{mM}$ $\mathrm{NaCl}, \mathrm{pH} 7 \cdot 5$. Tracking dye without EDTA was then added and the samples centrifuged at $14000 \mathrm{rpm}$ for four minutes to remove the asbestos bodies or fibres. Samples were loaded on to a $0.6 \%$ agarose gel and electrophoresis was carried out to separate closed circular superhelical DNA from DNA with single strand breaks. After staining with ethidium bromide, the gel was transilluminated with ultraviolet light and photographed. The density of the bands was determined by integrated scanning densitometry. The percentage of DNA with single strand breaks was then determined as described previously. ${ }^{29}$ All results are expressed relative to the control DNA (DNA treated under identical conditions minus asbestos bodies or amosite). To determine whether iron was responsible for the formation of single strand breaks, desferrioxamine B (10 $\mathrm{mM})$ was preincubated with the asbestos bodies for 24 hours before and throughout the 30 minutes incubation with DNA and the other components.

To find the effect that ethanol and chlorox treatment had on the reactivity of iron, amosite was treated with ethanol $(95 \%)$ and then chlorox (sodium hypochlorite, $5 \cdot 25 \%$ ) for the time periods used in the isolation of the asbestos bodies. The fibres were then collected on a $0.2 \mu \mathrm{m}$ filter, washed with $50 \mathrm{mM}$ $\mathrm{NaCl}$, and resuspended in $50 \mathrm{mM} \mathrm{NaCl}$. The ability of the treated fibres to induce the 

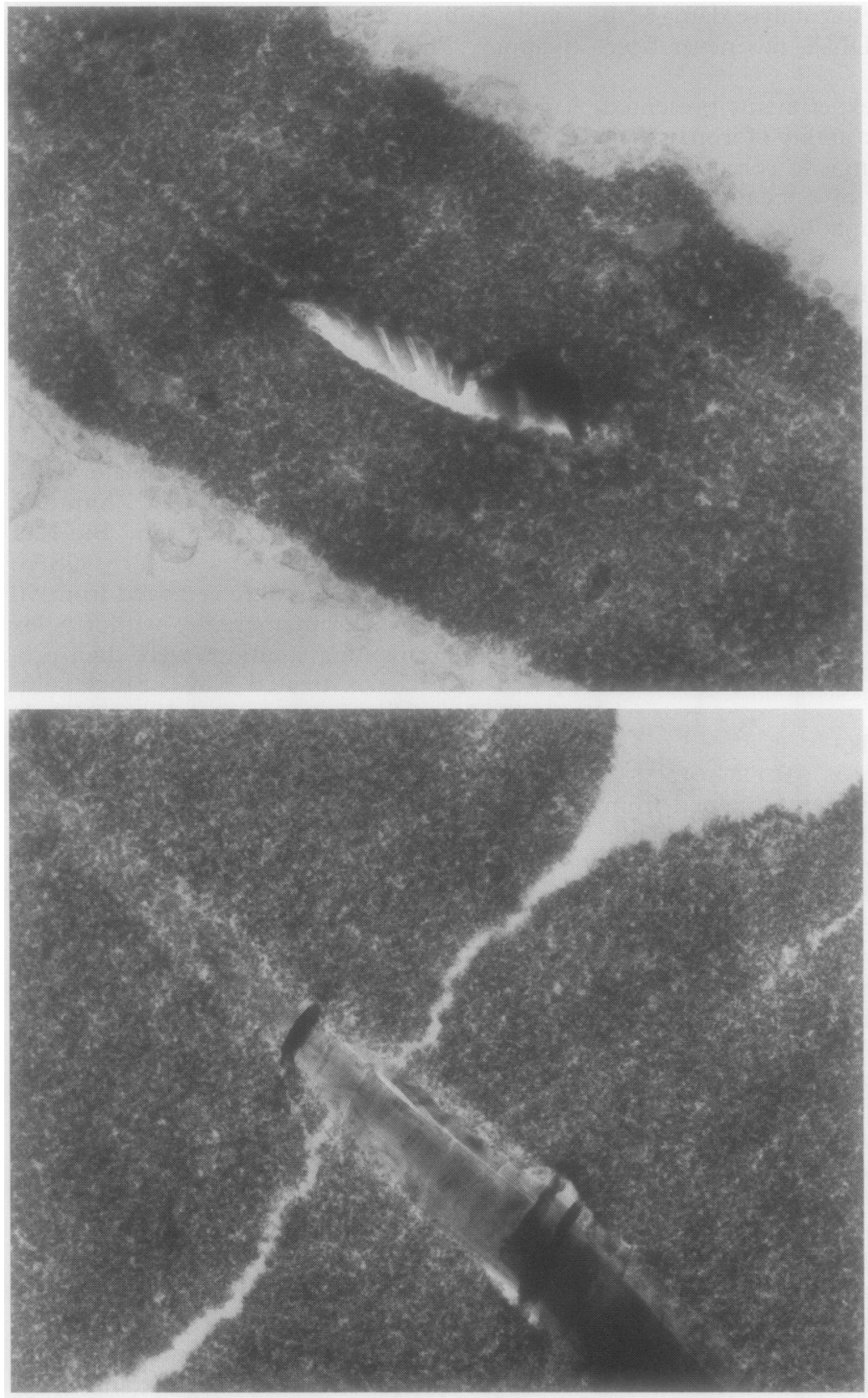

Figure 1 Transmission electron micrographs of cross sections of amosite asbestos bodies: top, in the tissue (originally $\times 40000$ ); bottom, isolated (originally $\times 40000$ ).

formation of DNA with single strand breaks at a concentration of $1 \mathrm{mg} / \mathrm{ml}$, which is known to induce the formation of DNA with single strand breaks, ${ }^{29}$ was determined and compared with untreated amosite.

All experiments were carried out at room temperature $\left(25^{\circ} \mathrm{C}\right)$ and in a room with incandescent yellow lights to prevent photochemical reduction of the iron. ${ }^{33}$ Each experiment was repeated at least twice and results are reported as the percentage of DNA with single strand breaks relative to the control untreated DNA.

\section{Results}

CHARACTERISATION OF ASBESTOS BODIES AND AMOSITE FIBRES

Electron microscopy and $x$ ray energy dispersive analysis of thin sections were used to compare the morphology of asbestos bodies in tissue with that of the isolated asbestos bodies. The electron micrographs in fig 1 show that the isolation procedure produced no visually significant changes in the cores or coats of the asbestos bodies. Typical $x$ ray spectra illustrated by fig 2(A and B) and an earlier work by Williams et al show very similar elemental composition before and after isolation of the asbestos bodies. ${ }^{34}$ The presence of lead and copper in the $x$ ray spectrum from the tissue asbestos body did not represent elements present in the core fibre. These elements were present as a result of the lead citrate tissue stain and the close proximity of the copper specimen support to the asbestos body core being analysed. The fragmented amosite core in the tissue fibre (fig 2(A)) was smaller than that in the isolated asbestos body (fig 2(B)). This resulted in a higher background and a greater iron to silicon ratio for the tissue asbestos body, as the iron coat comprised more of the sample area being analysed. The isolated asbestos body section was not stained with lead citrate and was more distant from the copper specimen support, resulting in detection of no lead and much lower concentrations of copper. The iron to silicon ratio for the isolated asbestos body core was typical of amosite.

To best compare the reactivity of amosite fibres with asbestos bodies containing amosite cores, amosite fibres were selectively filtered to obtain length distributions that closely resembled those of the asbestos bodies. Figure 3(A and B) indicates the degree of similarity between the two preparations. The isolated asbestos bodies had a mean length of $61.2 \mu \mathrm{m}$ and the sized fibres had a mean length of $45.6 \mu \mathrm{m}$. The asbestos bodies ranged from 17 to $244 \mu \mathrm{m}$ and the fibres 10 to $147 \mu \mathrm{m}$ in length.

\section{THE FORMATION OF DNA SINGLE STRAND}

BREAKS CATALYSED BY ASBESTOS BODIES

Table 1 shows that incubation of asbestos bodies with $\varphi \mathrm{X} 174$ RFI DNA and ascorbate for 30 minutes resulted in the formation of very low, but statistically significant ( $\mathrm{p}<$ 0.025 , one sided Student's $t$ test) amounts of single strand breaks in DNA. The addition of citrate or EDTA greatly enhanced (up to 7.7fold) this reactivity. Amosite $(5000$ fibres/reaction) did not induce detectable amounts of DNA with single strand breaks in the presence or absence of a chelator. The formation of DNA with single strand breaks was not detected with asbestos bodies or amosite fibres in the absence of ascorbate (data not shown).

The iron chelator, desferrioxamine $B$, which inhibits redox reactions of iron, was incubated with asbestos bodies to determine whether iron was responsible for the formation of DNA single strand breaks catalysed by asbestos bodies. Desferrioxamine B completely inhibited ascorbate dependent formation of DNA single strand breaks catalysed by asbestos bodies in the presence or absence of citrate or EDTA (data not shown). 
Figure 2 Energy amosite asbestos body (B) isolated. dispersive $x$ ray spectra of cores, $(A)$ in the tissue or

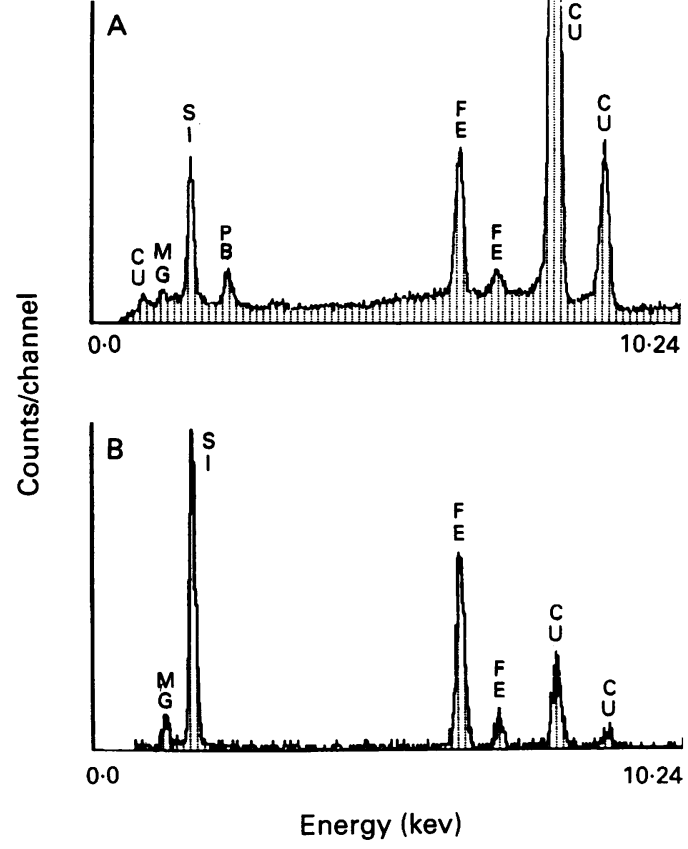

Figure 3 Size distribution of $(A)$ asbestos bodies and (B) amosite fibres.

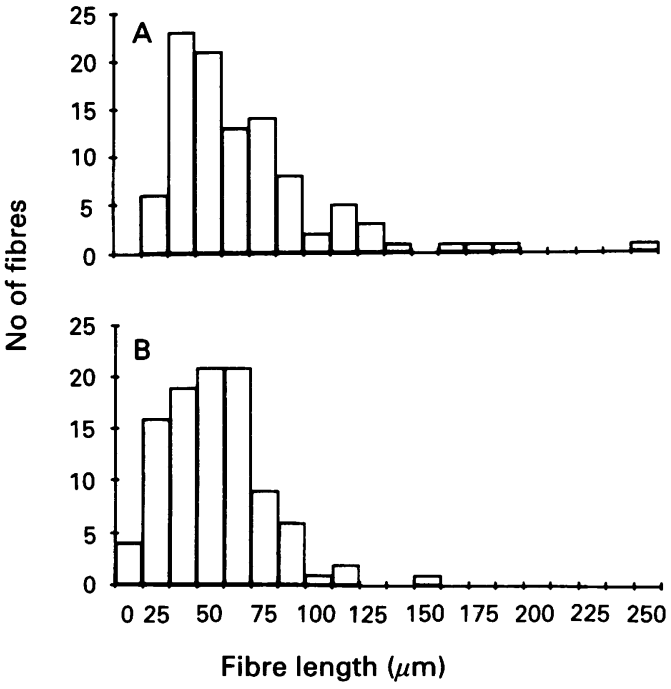

To find the effect that ethanol and chlorox treatment might have on the reactivity of iron associated with fibres, amosite $(1 \mathrm{mg} / \mathrm{ml})$ was treated as described and the reactivity of the pretreated sample with DNA was compared with untreated amosite. Table 2 shows that under redox cycling conditions (in the presence of ascorbate), treated and untreated amosite catalysed the same amounts of single strand breaks in DNA in the presence or absence of EDTA.

Table 1 The formation of DNA single strand breaks catalysed by asbestos bodies or amosite

\begin{tabular}{|c|c|c|}
\hline \multirow[b]{2}{*}{ Additionst } & \multicolumn{2}{|c|}{ DNA with single strand breaks (\%)* } \\
\hline & Asbestos bodies & Sized amosite \\
\hline $\begin{array}{l}\text { None } \\
\text { Citrate } \\
\text { EDTA }\end{array}$ & $\begin{array}{l}10(4) \\
21(5) \\
77(7)\end{array}$ & $\begin{array}{l}\text { ND } \ddagger \\
\text { ND } \\
\text { ND }\end{array}$ \\
\hline \multicolumn{3}{|c|}{$\begin{array}{l}{ }^{\star} \text { Results are mean }(\mathrm{SD})(\mathrm{n} \geqslant 3) \text { and are relative to the con- } \\
\text { trol, untreated DNA. } \\
\dagger \text { Assays contained } 5000 \text { asbestos bodies or amosite fibres } \\
\text { incubated with } 0.5 \mu \mathrm{g} \varphi 174 \text { RFI DNA and } 1 \mathrm{mM} \text { ascorbate } \\
\text { for } 30 \text { minutes under the indicated conditions. } \\
\ddagger \mathrm{ND} \text {, not detectable ( } \leqslant 5 \% \text { DNA with single strand breaks). }\end{array}$} \\
\hline
\end{tabular}

Table 2 DNA single strand breaks catalysed by ethanol/ chlorox treated or untreated amosite

\begin{tabular}{lll}
\hline \multirow{2}{*}{ Additionst } & \multicolumn{2}{l}{ DNA with single strand breaks (\%) } \\
\cline { 2 - 3 } & Untreated amosite & Treated amosite \\
\hline None & 21 & 19 \\
EDTA & 52 & 50 \\
\hline \multirow{2}{*}{ Results are represented as the average of two experiments } \\
and are relative to the control, untreated DNA. \\
†Assays contained 1 mg/ml treated or untreated amosite incu- \\
bated with $0.5 \mu \mathrm{g} \varphi \mathrm{X174}$ RFI DNA for 30 minutes under the
\end{tabular}
bated with $0.5 \mu \mathrm{g} \varphi \mathrm{X}$
indicated conditions.

\section{Discussion}

The results presented here show that amosite core asbestos bodies isolated from human lungs catalyse the formation of DNA single strand breaks in vitro. Two lines of evidence strongly suggest that the iron was responsible for the induction of single strand breaks: firstly inhibition of the formation of single strand breaks in DNA by desferrioxamine B, and secondly enhanced formation of single strand breaks in the presence of EDTA. Desferrioxamine B binds iron (Fe (III)) and completely inhibits its reaction with oxygen under the conditions used in these experiments. Desferrioxamine B is also known to completely inhibit crocidolite or amosite dependent formation of SSBs by fibres suspended at $1 \mathrm{mg} / \mathrm{ml}^{29}$ It is known that EDTA enhances the reaction of iron with oxygen. ${ }^{35}$ Also EDTA enhances crocidolite dependent oxygen consumption, ${ }^{21}$ hydroxyl radical formation, ${ }^{22}$ and induction of DNA in vitro. ${ }^{29}$

Although these results are the first to show that iron associated with asbestos bodies is reactive in vitro, the role of iron in the biochemical reactivity of uncoated asbestos fibres has been studied extensively. ${ }^{20}$ Iron is responsible for asbestos dependent oxygen consumption, ${ }^{21} 22$ hydroxyl radical formation, ${ }^{22-24}$ lipid peroxidation, ${ }^{25}$ and damage to DNA $^{27} 2930$ in vitro. There is also evidence to suggest that iron may play a part in the biological effects of asbestos in cultured cells. ${ }^{20}$

Asbestos bodies catalysed the formation of DNA single strand bodies in vitro whereas comparable numbers of similarly sized amosite fibres did not catalyse detectable amounts of single strand breaks. This may be the result of increased amounts of reactive iron associated with asbestos bodies compared with uncoated amosite fibres. Although amosite fibres were fractionated to obtain a range of lengths closer to those of the asbestos bodies, there was no way to correct for the greatly increased diameter of the asbestos bodies resulting from the deposits on the surface. Therefore, the increased average surface area of the asbestos bodies very likely contributed to the increased availability of iron and damage to DNA dependent upon asbestos bodies. Although the sized amosite fibres used in these studies did not damage DNA at 5000 fibres/reaction, both amosite and crocidolite have previously been shown to catalyse the formation of DNA single strand breaks at $1 \mathrm{mg} / \mathrm{ml},{ }^{29}$ a much higher concentration of fibres than the concentration 
of asbestos bodies or amosite fibres used here.

Addition of a low molecular weight chelator, citrate or EDTA, greatly enhanced the reactivity of asbestos bodies with DNA. The increased reactivity suggested that mobilisation of iron from the bodies was important. This is consistent with earlier work that showed that mobilisation of iron by low molecular weight chelators greatly enhanced crocidolite dependent oxygen consumption, ${ }^{21} 22$ hydroxide radical formation, ${ }^{22}$ and formation of DNA single strand breaks ${ }^{29}$ in vitro. Although EDTA is not present in vivo, there are many organic acids, including citrate, amino acids, and fatty acids that are present and might serve as chelators for iron mobilisation from asbestos bodies or uncoated asbestos fibres.

The ethanol and chlorox treatment used to isolate the asbestos bodies did not affect reactivity of iron associated with, or mobilised from, uncoated amosite fibres. This does not, however, exclude the possibility that the mucopolysaccharides or proteins that coat the bodies were removed during the isolation procedure. It is not known how these constituents of the coat material may affect the reactivity of the deposited iron in vivo. This will be the subject of future investigations.

In conclusion, the results presented here suggest that iron deposited on to asbestos fibres in vivo may be reactive. The increase in surface area and availability of iron on asbestos bodies compared with the core fibres may result in more damage to cellular macromolecules, rather than less, as has been previously proposed.

This work was supported by a grant from the Willard Eccles Chantable Foundation to AEA and NIH Grant ES05782 to AEA

1 Mossman BT. Carcinogenic potential of asbestos and nonasbestos fibers. Environmental Carcinogen Reviews 1988; C6(2):151.95

2 Churg AM, Warnock ML. Asbestos and other ferruginous bodies; Their formation and clinical significance. $A m \mathcal{F}$ Pathol 1981;102:447-56.

3 Pooley FD. Asbestos bodies, their formation, composition and character. Environ Res 1972;5:363-79.

4 Davis JMG. Further observations on the ultrastructure and chemistry of the formation of asbestos bodies. Exp Mol Pathol 1970;13:346-58.

5 Barclay WR, Craighead JE, Cugell DW, et al. A physician's guide to asbestos-related diseases. $\mathscr{}$ AMA 1984; 252:2593-7

6 Suzuki Y, Churg J. Structure and development of the asbestos body. Am 7 Pathol 1969;55:79-107.

7 Gross P, Cralley LJ, deTreville RTP "Asbestos" bodies: their nonspecificity. Am Ind Hyg Assoc f 1967;28:541-2.

8 Gross P, Tuma J, deTreville RTP Unusual ferruginous bodies. Arch Environ Health 1971;22:534-7.

9 Craighead JE. Asbestos-associated diseases. Arch Pathol Lab Med 1982;106:542-96.

10 Langer AM, Rubin IB, Selikoff IJ. Chemical characterisation of asbestos body cores by electron microprobe analysis. $\mathcal{F}$ Histochem Cytochem 1972;20:723-34
11 Holden J, Churg A. Asbestos bodies and the diagnosis of asbestosis in chrysotile workers. Environ Res 1986; asbestosis

12 Dodson RF, Williams MG, O'Sullivan MF, Corn CJ, Greenberg SD, Hurst GA. A comparison of the ferruginous body and uncoated fiber content in the lungs of former asbestos workers. Am Rev Respir Dis 1985; 132:143-7.

13 Dodson RF, O'Sullivan MF, Williams MG, Hurst GA Analysis of cores of ferruginous bodies from former asbestos workers. Environ Res 1982;28:171-8.

14 Dodson RF, Williams, MG, Hurst, GA. Method for removing the ferruginous coating from asbestos bodies. r Toxicol Environ Health 1983;11:959-66.

15 Morgan A, Holmes A. The enigmatic asbestos body: its formation and significance in asbestos-related disease. Environ Res 1985;38:283-92.

16 Dodson RF, Greenberg SD, Williams MG, Corn CJ, O'Sullivan MF, Hurst GA. Asbestos content in lungs of occupationally and nonoccupationally exposed individuals. $\mathcal{F A M A}$ 1984;252:68-71.

17 Davis JMG. Asbestos dust as a nucleation center in the calcification of old fibrous tissue lesions, and the possible association of this process to the formation of asbestos bodies. Exp Mol Pathol 1970;12:133-47.

18 Governa M, Rosanda C. A histochemical study of the asbestos body coating. Br F Ind Med 1972;29:154-9.

19 Davis JMG. The ultrastructure of asbestos bodies from human lung. British fournal Experimental Pathologv 1964;45:642-6.

20 Lung LG, Aust AE. Iron-catalyzed reactions may be responsible for the biochemical and biological effects of asbestos. Biofactors 1991;3:83-9.

21 Lund LG, Aust AE. Mobilization of iron from crocidolite asbestos by certain chelators results in enhanced crocidolite-dependent oxygen consumption. Arch Biochem Biophys 1991;287:91-6.

22 Aust AE, Lund LG. Iron mobilization from crocidolite results in enhanced iron-catalyzed oxygen consumption and hydroxyl radical generation in the presence of cysteine. In: Brown RC, Hoskins JA, Johnson NF, eds. Mechanisms in fibre carcinogenesis. Vol 223. NATO ASI Series. New York: Plenum Press, Life Sciences, 1991:397-405.

23 Weitzman SA, Graceffa P. Asbestos catalyzes hydroxyl and superoxide radical generation from hydrogen peroxide. Arch Biochem Biophys 1984;228:373-6.

24 Kennedy TP, Dodson R, Rao NV, et al. Dusts causing pneumoconiosis generate $\mathrm{OH}$ and produce hemolysis by acting as Fenton catalysts. Arch Biochem Biophys acting as Fenton

25 Weitzman SA, Weitberg AB. Asbestos-catalyzed lipid peroxidation and its inhibition by desferroxamine. Biochem f 1985;225:259-62.

26 Goodlick LA, Pietras LA, Kane AG. Evaluation of the causal relationship between crocidolite asbestos-induced lipid peroxidation and toxicity to macrophages. Am Rev Respir Dis 1989;139:1265-73.

27 Turver CJ, Brown RC. The role of catalytic iron in asbestos induced lipid peroxidation and DNA-strand breakage in C3H10T1/2 cells. Br f Cancer 1989:56: $133-6$

28 Turver CJ, Poole A, Brown RC. Lipid peroxidation and the generation of malondialdehyde in crocidolite-treated cell cultures. In: Beck EG, Bignon J, eds. In vitro effects cell cultures. In: Beck EG, Bignon J, eds. In vitro effects of mineral dusts. Vol G3. NAT

29 Lund LG, Aust AE. Iron mobilization from crocidolite asbestos greatly enhances crocidolite-dependent formation of DNA single-strand breaks in $p$ X174 RFI DNA. Carcinogenesis 1992;13:637-42.

30 Aust AE, Lund LG. The role of iron in asbestos-catalyzed damage to lipids and DNA. In: Reddy CC, Hamilton $\mathrm{GA}$, Madyastha KM, eds. Biological oxidation systems. Vol II. Orlando: Academic Press, 1990:597-605.

31 Spur AR. A low-viscosity epoxy resin embedding medium for electron microscopy. foumal of Ultrastructure Research 1969;26:31-43.

32 Maniatis T, Fritsch EF, Sambrook J. Molecular cloning: a laboratory manual. Cold Spring Harbor, NY: Cold Spring Harbor Laboratory, 1984.

33 Chao C-C, Aust AE. Photochemical reduction of ferric iron by chelators results in DNA strand breaks. Arch Biochem Biophys 1993;300:544-50

34 Williams MG, Dodson RF, Corn C Hurst GA A procedure for the isolation of amosite asbestos and ferrugidure for the isolation of amosite asbestos and ferruginous bodies from lung tissue
Environ Health $1982 ; 10: 627-38$

35 Miller DM, Buettner GR, Aust SD. Transition metals as catalysts of "autoxidation" reactions. Free Radic Biol Med 1990;8:95-108 